DOI: $10.33766 / 2524-0323.89 .23-33$

УДК 342.3

А. Я. Палюх,

докторант кафедри конституційного

права та прав людини

Національної академії внутрішніх справ

(м. Киӥв, Україна)

e-mail: andrewpaliuch@gmail.com

iDhttps://orcid.org/0000-0001-9856-9147

\title{
ПРАВОВИЙ СТАТУС СУБ'ЄКТІВ ДЕРЖАВНО-ПРАВОВОГО РЕГУЛЮВАННЯ СФЕРИ ФІЗКУЛЬТУРИ І СПОРТУ: ТЕОРЕТИЧНІ ТА КОНСТИТУЦЙНО-ПРАВОВІ АСПЕКТИ
}

У статті здійснено грунтовний аналіз правового статусу суб́єктів державноправового регулювання сфери фізичної культури і спорту в Україні. Розкрито його теоретичні особливості, зокрема різноманітні концептуальні підходи до визначення природи й поняття правового статусу суб'єктів права, правовідносин тощо. Приділено увагу різновидам такого статусу, зокрема конституційно-правовому статусу суб'єктів державно-правового регулювання сфери фізичної культури і спорту. На основі вивчення складових елементів, а також результатів його реалізації виявлено певні проблеми в даній сфері, окреслено напрями й шляхи удосконалення такого статусу, відповідних нормативно-правових засад і практики реалізації.

Ключові слова: фізична культура, спорт, спортивні правовідносини, держава, нормативно-правове регулювання, законодавство, органи державної влади.

Постановка проблеми. Розширення кола учасників фізкультурно-спортивних відносин не є винятком із загальних тенденцій розвитку інституту правосуб'єктності, статусу суб'єктів правовідносин. Водночас специфіка практично кожної сфери життєдіяльності людини і суспільства накладає свої особливості й на згадані інститути. Сфера фізкультури і спорту належить до тих, які регламентовані переважно на загальнонаціональному рівні в більшості державах світу. Підтвердженням цього є відповідні положення Конституції України 1996 р., Закону України «Про фізичну культуру і спорт» 1993 р. та низки інших. Причому інститут правового статусу суб'єктів правового регулювання в галузі фізкультури і спорту, на наш погляд, не є усталеним і стабільним, на відміну від загальної чисельності таких суб'єктів. Певні модифікації супроводжуються модернізацією спеціально уповноважених органів на види діяльності, варіюється залежно від просторових і часових параметрів.

Зниження уваги держави до забезпечення здоров'я людини і нації, громадського здоров'я, загального стану фізичної культури і спорту змушує все ж таки звернути увагу наукової спільноти на теоретичні основи та практичне втілення реального правового статусу згаданих вище суб'єктів.

Аналіз останніх досліджень і публікацій. Науковий доробок сучасних учених, слід зауважити, не є обмеженим стосовно теоретичних, конституційно-правових, адміністративно-правових, цивільно-правових, господарсько-правових та інших аспектів інституту правового статусу суб'єктів права, правовідносин. Зокрема, варто згадати внесок таких дослідників, як: С. Алексеєв, А. Апаров, О. Бакумов,

(C) Палюх А. Я., 2020 
О. Біляєв, Н. Богданова, В. Журавель, Н. Камінська, М. Козюбра, О. Клименко, Ю. Назарко, Б. Островська, А. Панчишин, П. Рабінович, О. Стрельченко, С. Стеценко, М. Тіхонова, А. Янчук та інші.

Прикметно, що не лише вчені-правознавці звертають увагу на дану проблематику, в інших галузях вітчизняної і зарубіжної науки розглядаються також певні аспекти діяльності суб'єктів регулювання сфери фізкультури і спорту, їх статусу, взаємозв' язку із суб'єктами сфери охорони здоров'я, фізичного виховання, державного управління, економіки тощо. Ідеться про наукові розвідки значної кількості дослідників, з-поміж яких: І. Гасюк, 3. Гладун, О. Мацегорін, О. Мельниченко, В. Москаленко, О. Ніколаєв, В. Пилипчук, О. Шамич, І. Шевчук та інші.

Формулювання цілей. Метою даної статті є здійснення аналізу правового статусу суб'єктів регулювання сфери фізичної культури і спорту в Україні, його складових елементів, а також розкриття теоретичних і конституційно-правових особливостей у даній площині. На цій основі важливо визначити напрями і шляхи удосконалення такого статусу, відповідних нормативно-правових засад і практики реалізації.

Виклад основного матеріалу. Як у теорії держави і права, так і в галузевих правових науках значна увага приділяється категорії правового статусу, його природі, поняттю й структурі. У підручниках та інших навчальних виданнях правовий статус розглядається переважно стосовно особи. Зокрема, Н. Камінська і О. Фатхутдінова в загальному вигляді розкривають поняття й природу «статусу» i «правового статусу». Остання категорія визначається як таке положення, що закріплено правовими нормами. Правовий статус особи, на їх думку, це система встановлених у нормативно-правових актах і гарантованих державою прав, свобод, обов'язків, відповідальності, відповідно до яких суб'єкти права (наділені правосуб'єктністю) координують свою діяльність [1, с. 79].

Як зауважують М. Цвік, В. Ткаченко, О. Петришин та інші автори, правовий статус особи - це сукупність усіх прав, обов' язків і законних інтересів суб'єктів права. Крім того, вони розрізняють конституційний і спеціальний статус. Перший є однаковим: основні права і свободи однаковою мірою належать громадянам, а спеціальний статус пов'язаний із різними природними і правовими чинниками, які обумовлюють певні особливості громадян [2, с. 342]. Водночас видається така позиція авторів неточною і неповно мірою розкривається поняття правового статусу, яке $є$ набагато ширшим. Т. Тарахонич трактує правовий статус як правове становище особи в суспільстві, а громадянина в державі, що відбиває їх фактичний стан та взаємодію із суспільством та державою. Це складне юридичне поняття, що містить такі основні елементів: правосуб'єктність, права, свободи, обов'язки, відповідальність [3, с. 764].

Дослідники В. Зайчук і Н. Оніщенко зауважують на поліаспектності та структурованості правового статусу, адже це система законодавчо встановлених і гарантованих державою прав, свобод, законних інтересів і обов'язків суб'єкта суспільних відносин [4, с. 366]. Можна погодитись, що це багатоаспектна, комплексна, універсальна категорія, що має чітку стабільну структуру та встановлює характер і принципи взаємодії суб'єктів суспільних відносин між собою, а також шляхом визначення прав, обов'язків та гарантій їх реалізації, визначає місце суб'єкта в 
системі правовідносин [5]. Як зазначають Н. Камінська й О. Фатхутдінова, правовий статус $€$ засобом нормативного закріплення основних принципів взаємодії особи та держави за допомогою зразків (моделей) поведінки суб'єктів, які, з одного боку, захищаються державою, а з іншого - схвалюються суспільством [1, с. 79].

Отже, це юридично закріплене становище або положення певного суб'єкта в суспільстві, що виражається в наявному комплексі його прав та обов'язків; меж його свободи, інших правових можливостей і відповідальності, відображає регламентовані взаємовідносини особи, суспільства і держави. Загалом правовий статус $є$ комплексною, багатоаспектною та інтеграційною категорією системного характеру, об'єктивно відображає позитивні та негативні особливості політикоправової системи держави. ІІї універсальний загальний характер поширюється на широке коло суб'єктів, тому включає різні статуси суб'єктів правовідносин (держави, суспільства, особи тощо). Притому відображаються індивідуальні їх особливості суб'єктів, реальне положення в системі суспільних відносин. Зміна правового статусу певної групи осіб в законодавстві може мати й цілеспрямований характер, наприклад, шляхом здійснення активних лобістських дій із цього питання [5, с. 58].

Розповсюджений підхід стосовно визначення структури і різновидів правового статусу за принципом «матрьошки». Його концепщія зводиться до розрізнення загального, спеціального та індивідуального правових статусів суб'єкта права [6-7]. Власне, врегульований переважно конституційними нормами перший з них відбиває правове становище абстрактних суб'єктів права одного типу, а спеціальний правовий статус відображає правове становище абстрактних суб'єктів права одного виду всередині певного типу, що значною мірою врегульовується галузевими нормами права. Й індивідуальний правовий статус вказує на відмінні ознаки конкретного суб'єкта права і регулюється норами різних галузей права, становлячи міжгалузевий правовий інститут у межах національної системи права.

Безумовно, виокремлюють конституційно-правовий статус, міжнародно-правовий статус, адміністративно-правовий статус, господарсько-правовий статус, цивільно-правовий та інші статуси. Наприклад, Н. О. Богданова зауважує, що конституційно-правовий статус містить такі елементи: місце суб'єкта в суспільстві й державі, його соціально-політичну роль та призначення; загальну правоздатність; права й обов'язки (компетенцію) суб'єкта та відповідальність; гарантії сталості та реальності правового становища суб'єкта [9, с. 5]. Узагалі характерним для конституційного права $є$ певний дуалізм правового статусу держави як специфічного об'єкта правового регулювання, оскільки держава - це форма політичного буття народу (субстантивний підхід), а також це система органів (інституційний підхід), а це зумовлює відповідну класифікацію правових норм, які опосередковують правове буття держави.

На наш погляд, оптимальним є інституційний підхід для належного реального вивчення правового статусу суб'єктів державно-правового регулювання в галузі фізкультури і спорту. Він дасть можливість розкрити їх сутнісно-функціональні характеристики, прослідкувати діалектику відносин «держава - державний механізм - орган державної влади - органи місцевого самоврядування - громадські організації - людина». Важливим $є$ також розкриття всіх елементів досліджуваної нами категорії - конституційно-правового статусу таких суб'єктів. 
Існують відмінні підходи до визначення суб'єктів фізкультурно-спортивних правовідносин, їх класифікації в доктринальних джерелах. Визначальним базовим документом, на нашу думку, при цьому є профільний основоположний нормативно-правовий акт у цій галузі, а саме Закон України «Про фізичну культуру і спорт» від 24.12.1993 р. Тут міститься розділ II. «Суб'єкти сфери фізичної культури і спорту», де законодавцем викладено відповідні ключові положення щодо суб'єктів сфери фізичної культури і спорту, їх правового статусу. Зокрема, суб'єкти сфери фізичної культури і спорту - фізичні або юридичні особи, які здійснюють свою діяльність із метою розвитку фізичної культури і спорту. Суб'єктами сфери фізичної культури і спорту є: фізичні особи, які займаються фізичною культурою і спортом, у тому числі спортсмени; фахівці сфери фізичної культури і спорту; заклади фізичної культури і спорту; відповідні органи влади (ст. 1 Закону) [9]. Тобто, на законодавчому рівні розкрито загальний підхід до визначення суб'єктів сфери фізичної культури і спорту.

Так М. Тіхонова, А. Сердюков та ряд інших дослідників виокремлюють три групи безпосередніх суб'єктів в галузі фізкультури і спорту: 1) Міністерство молоді та спорту Украӥни, діяльність якого поширюється на всю територію України; на місцях регулювання фізичною культурою і спортом здійснюють спеціалізовані відділи в органах місцевих адміністрацій; 2) центри олімпійської, параолімпійської підготовки, різні неприбуткові союзи в залежності від виду спорту, освітні заклади та наукові організації у сфері спорту, спортивний арбітражний суд, міжнародні спортивні організації тощо; 3) різна комерційні проекти, що створені у формі акціонерного товариства тощо [11, с. 50-53; 11]. Також слід звернути уваги, що не всі 3 таких суб'єктів наділені повноваження, спрямованими на державно-правове регулювання сфери фізкультури і спорту.

У Конституції України 1996 року, а точніше, у його ст. 49 закріплено положення, відповідно до якого «держава дбає про розвиток фізичної культури і спорту, забезпечує санітарно-епідемічне благополуччя» [12]. Тобто, в Украӥні саме на державу в особі відповідних органів покладається обов'язок сприяти зміцненню фізичного компоненту здоров'я населення, спорту тощо. Це означає, що в системі законодавства мають бути деталізовані відповідні конституційні положення, у тому числі стосовно конституційно-правового статусу суб'єктів правового регулювання сфери фізкультури і спорту в Україні. Проте постає питання, чи належним чином врегулювано й забезпечено на практищі згадані положення?

Так, повертаючись до Закону Украӥни «Про фізичну культуру і спорт» 1993 р., згадаємо, що у його ст. 3 регламентовано засади державної політики у сфері фізичної культури і спорту, у ст. 5 - державне управління у сфері фізичної культури і спорту, яке здійснюється центральним органом виконавчої влади, що забезпечує формування державної політики у сфері фізичної культури та спорту, центральним органом виконавчої влади, що реалізує державну політику у сфері фізичної культури та спорту, за сприяння, відповідно, інших органів державної влади та органів місцевого самоврядування. Також ст. 6 Закону встановлює повноваження центрального органу виконавчої влади, що забезпечує формування державної політики у сфері фізичної культури та спорту, центрального органу виконавчої влади, що реалізує державну політику у сфері фізичної культури та 
спорту, та інших центральних органів виконавчої влади у сфері фізичної культури і спорту [10].

Як бачимо, лише певні елементи правового статусу суб'єктів державно-правового регулювання сфери фізкультури і спорту визначені в даному законі. У розділі IV Основного Закону України регламентується конституційно-правовий статус єдиного органу законодавчої влади в Україні, яким є парламент, - Верховна Рада України. За ст. 85 визначено чітко повноваження прийняття законів, затвердження загальнодержавних програм тощо [13]. Згідно із Законом України «Про Регламент Верховної Ради України» деталізуються статусні, процедурні та інші характеристики конституційно-правового статусу парламенту України [16]. Оприлюднення рішень Верховної Ради України здійснюється через офіційні парламентські видавництва щотижневого нормативного бюлетеню «Відомості Верховної Ради України» та газети «Голос України», систематичне видання яких дає «змогу наповнити реальним змістом принципи демократичності, відкритості, транспарентності та доступності в діяльності законодавчого органу» [17, с. 37-38].

Важливими здобутками на шляху реалізації даного статусу зауважимо значну кількість законів, прийнятих задля забезпечення державно-правового регулювання сфери фізкультури і спорту в Україні. Так, крім згаданих, це і Цивільний кодекс України, і Господарський кодекс України, і Сімейний кодекс України, і Закони України «Про сприяння соціальному становленню та розвитку молоді в Украӥні», «Основи законодавства України про охорону здоров'я», «Про громадські об'єднання», «Про підтримку олімпійського, параолімпійського руху та спорту вищих досягнень в Україні», «Про міжнародне приватне право» та ін.

На реалізацію положень ст. 49 Конституції України, ряду деяких інших пов'язаних ії статей, Закону України «Про фізичну культуру і спорт» 1993 р., спрямована діяльність Президента України як глави держави. Зокрема, підготовка і прийняття значної кількості указів і розпоряджень Президента свідчать про реалізацію його статусу як суб'єкта державно-правового регулювання сфери фізкультури і спорту. Це укази Президента України «Про Національну стратегію з оздоровчої рухової активності в Украӥні на період до 2025 року «Рухова активність - здоровий спосіб життя - здорова нація» 2016 р.; «Про призначення стипендій Президента України дпя видатних спортсменів із паралімпійських і деолімпійських видів спорту та їх тренерів» 2013 р.; Розпорядження Президента України «Про надання підтримки Міжнародному юнацькому турніру з футболу на Кубок Президента Украӥни» 2013 р. тощо.

Не можна не згадати й такі результати реалізації правового статусу таких суб'єктів державно-правового регулювання досліджуваної сфери як органи державної виконавчої влади. Це, зокрема, Постанови Кабінету Міністрів України «Про затвердження Порядку та умов обов'язкового державного страхування спортсменів вищих категорій» 1995 р., «Про затвердження Порядку створення штатних спортивних команд резервного спорту» 2010 р.; «Про затвердження Положення про центр олімпійської підготовки» від 07.09.2011 р. № 948; «Про затвердження Порядку надання навчальному закладу статусу спеціалізованого навчального закладу спортивного профілю» 2011 р., «Про заохочення спортсменів і тренерів з олімпійських та неолімпійських видів спорту» 2016 р.; Розпорядження Кабінету Міністрів України 
«Про схвалення Концепщії Загальнодержавної цільової соціальної програми розвитку шахів «Інтелект нації» на 2013-2020 роки» від 2012 р. 3-поміж Наказів Мiністерства молоді та спорту України: «Про проведення навчально-тренувального збору національної збірної команди України з дзюдо зі спеціальної підготовки до чемпіонату Європи» 2019p;; «Про затвердження Положення про Єдину спортивну класифікацію України» 2013 р.; «Про затвердження Порядку визнання видів спорту, включення їх до Реєстру визнаних видів спорту в Україні, порядок його ведення» 2014 р.; «Про затвердження Положення про національні збірні команди 3 видів спорту, визнаних в Україні» 2015 р. тощо [18-19].

Обмежений обсяг даної публікації не дозволяє дослідити особливості реалізації правового статусу всіх існуючих суб'єктів державно-правового регулювання сфери фізкультури і спорту в Україні, а також відповідний зарубіжний досвід. Інший напрям перспективних подальших досліджень у цьому напрямі, на наш погляд, полягає в розкритті специфіки елементів правового статусу суб'єктів державно-правового регулювання сфери фізкультури і спорту, особливо відповідальності таких суб'єктів тощо.

Висновки. Отже, досліджувана сфера фізкультури і спорту, фізкультурноспортивні відносини, якіє об'єктом державно-правового регулювання в Україні, визначаються комплексним характером. У законодавстві й доктринальних джерелах згадуються переважно суб'єкти сфери фізкультури і спорту (насамперед у профільному Законі Украӥни «Про фізичну культуру і спорт» 1993 р. та ін.). Лише системне і комплексне вивчення існуючої нормативно-правової бази України дозволяє розрізняти суб'єктів сфери фізкультури і спорту, суб'єктів державно-правового регулювання даної сфери, можливо, навіть суб'єктів правового впливу в галузі фізкультури і спорту.

Зокрема, суб'єкти сфери фізкультури і спорту в Україні є досить широкою категорією; законодавець до них включає такі категорії, як: фізичні особи, які займаються фізичною культурою і спортом, у т. ч. спортсмени; фахівці сфери фізичної культури і спорту; заклади фізичної культури і спорту; відповідні органи влади. Фактично лише останні є суб'єктами державно-правового регулювання сфери фізкультури і спорту. 3 огляду на функщіональний критерій, виокремлено з-поміж останніх Президента України, Верховну Раду України, Кабінет Міністрів України, центральний орган виконавчої влади, що реалізує державну політику у сфері фізичної культури та спорту, за сприяння відповідно інших органів державної влади й органів місцевого самоврядування.

Слід зазначити, що коло суб'єктів державно-правового регулювання сфери фізичної культури і спорту є вужчим, ніж відповідне коло суб'єктів правового регулювання даної сфери. Наприклад, до другої групи суб'єктів належать органи місцевого самоврядування в Україні. Основним суб'єктом державно-правового регулювання сфери фізичної культури і спорту, звісно, є держава, проте потребує уточнення iї конституційно-правовий статус.

Система нормативно-правового регулювання фізичної культури і спорту в Україні засвідчує, що правотворчі та правозастосовні повноваження, інші елементи правового статусу суб' єктів державно-правового регулювання сфери фізкультури і 
спорту, реалізуються переважно на таких основних рівнях конституційно-правового регулювання: конституційний, законодавчий (у вузькому розумінні базується на законах), підзаконний.

Взагалі правовий статус суб'єктів державно-правового регулювання сфери фізкультури і спорту є комплексною, багатоаспектною та інтеграційною категорією системного характеру, що об'єктивно відображає позитивні та негативні особливості політико-правової системи держави. Це юридично закріплене становище або положення спеціально уповноважених суб' єктів, що виражається в наявному комплексі його повноважень, обов'язків; відповідальності, відбиває регламентовані взаємовідносини 3 іншими учасниками суспільних відносин відповідних сфер життєдіяльності.

На нашу думку, спостерігається до певної міри несистемність та непослідовність реалізації правового статусу суб'єктів державно-правового регулювання сфери фізичної культури і спорту, іноді алогічність чи дублювання положень деяких нормативно-правових актів у цій галузі тощо. Одним із шляхів виходу з такої ситуації $є$ імплементація міжнародно-правових стандартів, оновлення, внесення відповідних змін і доповнень до чинного законодавства України, його систематизація 3 метою удосконалення правового статусу суб'єктів державно-правового регулювання сфери фізкультури і спорту.

\section{Використані джерела:}

1. Камінська Н. В., Горун О. В., Фатхутдінова О. В. Теорія держави та права : навч. посіб. К.: КНТ, 2011. 216 с.

2. Загальна теорія держави та права: підручник для студентів юридичних спеціальностей вищих навчальних закладів / За ред. М. В. Цвіка, В. Д. Ткаченка, О. В. Петришина. Харків: Право, 2002. 432 с.

3. Тарахонич Т. Правовий статус. Міжнародна поліцейська енциклопедія: У 10 т. / Відп. ред. Ю. І. Римаренко, Я. Ю. Кондратьєв, В. Я. Тацій, Ю. С. Шемшученко. К.: Конщерн «Видавничій Дім «Ін Юре», 2005. Т. І. С. 764.

4. Теорія держави і права: Академічний курс / за ред. В. О. Зайчука, Н. М. Оніщенко. Київ: Юрінком Інтер, 2008.

5. Нестерович В. Ф. Основні підходи до визначення поняття «лобіювання». Вісник Луганського держаһного університету внуттішніх справ імені Е. О. Дідоренка. 2010. № 1. С. 50-58.

6. Панчишин А. В. Поняття, ознаки та структура категорії «правовий статус». Часопис Київського університету права. 2010. № 2. С. 95-98.

7. Бакумов О. С. Юридична відповідальність як елемент правового статусу держави: теоретико-правові аспекти. Актуальні проблеми держави і права 2019, вип. 83. Одеса. C. 3-13. DOI https://doi.org/10.32837/apdp.v0i83.112

8. Козюбра М. І., Погребняк С. П., Цельєв О. В., Матвєєва Ю. І. Загальна теорія права: підручник / за заг. ред. проф. Козюбри М. І. Київ: Ваіте, 2016. 392 с.

9. Богданова Н. А. Категория статуса в конституционном праве. Вестник Московского университета. Серия 11. Право. 1998. № 3. С. 3-20.

10. Про фізичну культуру і спорт: Закон України від 24.12.1993 р. № 3808-XII. Відомості Верховної Ради України. 1994. № 14. Ст. 80. URL: http://zakon1.rada.gov.ua

11. Тіхонова М. А. Суб'єкти правовідносин, що складаються у сфері фізичної культури і спорту. Правовий часопис Донбасу. 2017. № 2 (60). С. 49 - 55. 
12. Сердюков А. В. Спортивное право как комплексная отрасль законодательства: автореф. Дисс. ... канд. юрид. наук: 12.00.01. Москва, 2010. 26 с.

13. Конституція України від 28.06.1996 р. № 254к/96-ВР. Відомості Верховної Ради України. 1996. № 30. Ст. 141.

14. Апаров А. М. Концепщія спортивного права: огляд ключових аспектів. Вісник Одеського начіонального університету ім. І. I. Мечникова. Правознавство. 2017. Том 22, № 1(30). C. 6-19.

15. Алексеев С. В. Правовые основы профессиональной деятельности в спорте: учебник для вузов. Москва, 2013. 517 с.

16. Про Регламент Верховної Ради України: Закон України, редакщія від 20.03.2020. Відомості Верховної Ради Украӥни. 2010, № 14-15, № 16-17, ст. 133. URL: https:// zakon. rada.gov.ua/laws/show/1861-17

17. Нестерович В. Роль друкованих парламентських видань у забезпеченні діалогової комунікації між парламентами та громадськістю. Віче. 2015. № 13. С. 34-38.

18. Палюх А. Я. Система нормативно-правового регулювання фізичної культури $\mathrm{i}$ спорту в Україні. Європейські перспективи. 2019. № 2. С. 19-25.

19. Палюх А. Я. Повноваження центральних органів влади у сфері фізичної культури і спорту в Україні. Верховенство права. 2019. № 2.

20. Kaminska N. V., Nazarko Y. V., Implementation of the right to health care in the countries of the European Union. Wiadomości Lekarskie. TOM LXXII, 2019, No 7, P. 1337-1342.

21. Мельниченко О. А. Державне регулювання розвитку фізичної культури та спорту: аналіз проведених досліджень і виокремлення перспективних напрямів Актуальні проблеми державного управління 2016, №1(49). С. $32-36$

22. Ніколаєв О. А. Роль держави у розвитку фізичної культури і спорту. Вісн. наук. праць ЧДУ ім. П. Могили. 2012. Вип. 182. Т. 194. С. 55-59.

23. Про Національну стратегію з оздоровчої рухової активності в Україні на період до 2025 року «Рухова активність - здоровий спосіб життя - здорова нація»: Указ Президента України № 42/2016 URL: http:/ / zakon1.rada.gov.ua

24. Державна цільова соціальна програма розвитку фізичної культури і спорту на період до 2020 року, затверджена постановою Кабінету Міністрів України від 1.03.2017 р. № 115. URL: http:/ / zakon.rada.gov.ua/laws/show/115-2017-п.

25. Палюх А. Я. Системний підхід у правовому регулюванні фізкультурно-спортивної сфери. Філософські та методологічні проблеми права. 2019. № 2. С. 92-99.

\section{References:}

1. Kamins`ka, N. V., Gorun, O. V., Fathutdinova, O. V. (2011) Teoriya derzhavy ta prava : navch. posib. K.: KNT. [in Ukrainian].

2. Zagal'na teoriya derzhavy ta prava (2002): pidruchnyk dlya studentiv yurydychnyx special'nostej vyshhy`x navchal'ny’x zakladiv. M. V. Czvik, V. D. Tkachenk, O. V. Petryshyn (Eds.). Xarkiv. [in Ukrainian].

3. Tarahonych, T. (2005). Pravovyj status. Mizhnarodna policejs'ka encyklopediya (Vol. 1-10) Yu. I. Rymarenko, Ya. Yu. Kondratyev, V. Ya. Tacij, Yu. S . Shemshuchenko (Eds.). Kyiv: Koncern "Vydavnychij Dim "In Yure. T. I. [in Ukrainian].

4. Teoriya derzhavy i prava (2008) Akademichnyj kurs. V. O. Zajchuk, N. M. Onishhenko (Eds.). Kyiv: Yurinkom Inter, 764-765. [in Ukrainian].

5. Nesterovych,V. F. (2010) Osnovni pidkhody do vyznachennya ponyattya «lobiyuvannya». Visnyk Luhans'koho derzhavnoho universytetu vnutrishnikh sprav imeni E. O. DidorenkaBulletin of the Luhansk State University of Internal Affairs Didorenko,1, 50-58. [in Ukrainian]. 
6. Panchyshy`n, A. V. (2010) Ponyattya, oznaky ta struktura kategoriyi «pravovyj status». Chasopys Kyyivs kogo universytetu prava - Law Review of Kyiv University of Law, 2, 95-98. [in Ukrainian].

7. Bakumov, O. S. (2019). Yurydychna vidpovidal`nist` yak element pravovogo statusu derzhavy: teoretyko-pravovi aspekty. Aktual ni problemy derzhavy i prava - Current Problems of State and Law, Odesa, issue 83, 3-13. DOI https://doi.org/10.32837/apdp.v0i83.112 [in Ukrainian].

8. Kozyubra, M. I., Pogrebnyak, S. P., Cel'yev, O. V., Matvyeyeva, Yu. I. (2016) Zagal’na teoriya prava: pidruchnyk. M. I. Kozyubra (Ed.) Kyiv: Vaite. [in Ukrainian].

9. Bogdanova, N. A. (1998) Kategoryya statusa v konstytucy`onnom prave. Vestnyk Moskovskogo unyversyteta. Seryya 11. Pravo - Moscow University Bulletin, 3, 3-20. [in Russian].

10. Pro fizychnu kulturu i sport: Zakon Ukrayiny (1993). Vidomosti Verhovnoyi Rady Ukrayiny- Information of the Verkhoona Rada of Ukraine. (1994) No 14. Art. 80. URL: http:// zakon1.rada.gov.ua [in Ukrainian].

11. Tihonova, M. A. (2017) Sub'yekty pravovidnosyn, shho skladayut sya u sferi fizychnoyi kul 'tury`i sportu. Pravoryj chasopys Donbasu - Law journal of Donbass, 2 (60), 49 - 55. [in Ukrainian].

12. Serdyukov, A. V. (2010). Sportyvnoe pravo kak kompleksnaya otrasl`zakonodatel`stva. Extended abstract of candidate's thesis. Moskva. [in Russian].

13. Konstytuciya Ukrayiny (1996). Vidomosti Verhoonoyi Rady Ukrayiny-Information of the Verkhouna Rada of Ukraine, 30, art. 141. [in Ukranian].

14. Aparov, A. M. (2017). Koncepciya sportyvnogo prava: oglyad klyuchovyx aspektiv. Visnyk Odes`kogo nacional nogo universytetu im. I. I. Mechnykova. Pravoznavstvo - Bulletin of the Odesa National University Herald. Vol. 22, 1(30), 6 - 19. [in Ukrainian].

15. Alekseev, S. V. (2013) Pravovye osnovy professyonal’noj deyatel'nosty v sporte: uchebnyk dlya vuzov. Moskva. [in Russian].

16. Pro Reglament Verxovnoyi Rady Ukrayiny (2010): Zakon Ukrayiny. Vidomosti Vehounoyi Rady Ukrayiny- Information of the Verkhovna Rada of Ukraine, 14-15, 16-17, art. 133. URL: https://zakon.rada.gov.ua/laws/show/1861.

17. Nesterovych, V. (2015) Rol' drukovanykh parlament s'kykh vydan' u zabezpechenni dialohovoyi komunikatsiyi mizh parlamentamy ta hromads'kistyu. Viche - Viche, 13, 34-38. [in Ukrainian].

18. Palyuh, A. Y. (2019). Systema normaty`vno-pravovogo regulyuvannya fizychnoyi kultury i sportu v Ukrayini. Yevropejski perspektyoy - European perspectives, 2, 19-25. [in Ukrainian].

19. Palyuh, A. Y. (2019). Povnovazhennya central’nyx organiv vlady u sferi fizychnoyi kul tury i sportu v Ukrayini. Verxovenstvo prava - Rule of Law, 2. [in Ukrainian].

20. Kaminska, N. V., Nazarko, Y. V. (2019) Implementation of the right to health care in the countries of the European Union. Wiadomości Lekarskie. Vol. LXXII, 7, 1337-1342. [in English].

21. Mel`nychenko, O. A. (2016). Derzhavne regulyuvannya rozvytku fizychnoyi kul tury ta sportu: analiz provedenyx doslidzhen ' i vyokremlennya perspektyvnyx napryamiv Aktual 'ni problemy derzhavnogo upravlinnya - Pressing Problems of Public Administration, 1(49), 32-36. [in Ukrainian].

22. Nikolayev, O. A. (2012). Rol` derzhavy u rozvytku fizychnoyi kul tury i sportu. Visn. nauk. pracz' ChDU im. P. Mogyly-Visn. of sciences. against the BSU them. P. Graves, 182, Vol. 194, 55-59. [in Ukrainian].

23. Pro Nacional`nu strategiyu z ozdorovchoyi ruxovoyi aktyvnosti v Ukrayini na period do 2025 roku "Ruxova aktyvnist' - zdorovyj sposib zhyttya - zdorova naciya". (2016) Ukaz Prezydenta Ukrayiny, 42/2016. URL: http:/ / zakon1.rada.gov.ua. [in Ukrainian]. 
24. Derzhavna cil`ova social `na programa rozvytku fizychnoyi kul`tury i sportu na period do 2020 roku (2017), zatverdzhena postanovoyu Kabinetu Ministriv Ukrayiny, 115. URL: http:// zakon.rada.gov.ua/laws/show/115-2017-p. [in Ukrainian].

25. Palyuh, A. Y. (2019) Systemnyj pidxid u pravovomu regulyuvanni fizkul turnosportyvnoyi sfery. Filosofs ki ta metodologichni problemy prava - Philosophical and Methodological Problems of Law, 2, 92-99. [in Ukrainian].

Стаття надійшла до редколегї 22.01.2020

Палюх А. Я., докторант кафедры конституционного права и прав человека Национальной академии внутренних дел (г. Киев, Украина)

\section{ПРАВОВОЙ СТАТУС СУБЪЕКТОВ ГОСУДАРСТВЕННО-ПРАВОВОГО РЕГУЛИРОВАНИЯ СФЕРЫ ФИЗКУЛЬТУРЫ И СПОРТА: ТЕОРЕТИЧЕСКИЕ И КОНСТИТУЦИОННО-ПРАВОВЫЕ АСПЕКТЫ}

В статъе осуществлен подробный анализ правового статуса субъектов государственно-правового регулирования сферы физической культуры и спорта в Украине. Раскрыто его теоретические особенности, в частности различные концептуальные подходы к определению природы и понятия правового статуса субъектов права, правоотношений и т. д. Уделено внимание разновидностям такого статуса, в частности конституционно-правовому статусу субъектов государственно-правового регулирования сферы физической культуры и спорта.

На основе изучения составляющих элементов, а также результатов его реализации выявлены определенные проблемы в данной сфере, определены направления и пути совершенствования такого статуса, соответствующих нормативно-правовых основ и практики реализации.

Ключевые слова: физическая культура, спорт, спортивные правоотношения, государство, нормативно-правовое регулирование, законодательство, органы государственной власти.

Palyukh A., Doctoral student of Constitutional Law and Human rights National Academy of Internal Affairs (Kyiv, Ukraine)

\section{LEGAL STATUS OF SUBJECTS OF STATE-LEGAL REGULATION OF THE SPHERE OF PHYSICAL EDUCATION AND THE SPORTS: THEORETICAL AND CONSTITUTIONAL-LEGAL ASPECTS}

The article provides a thorough analysis of the legal status of the subjects of state regulation of the sphere of physical culture and sports in Ukraine. Its theoretical features, in particular, various conceptual approaches to defining the nature and concept of the legal status of the subjects of law, 
legal relations, etc., are revealed. Attention is paid to the varieties of such status, in particular, the constitutional and legal status of the subjects of state and legal regulation of the sphere of physical culture and sports.

The subjects of the sphere of physical culture and sports in Ukraine are quite broad category, the legislator to them includes: physical persons engaged in physical culture and sports, including sportsmen; specialists in the field of physical culture and sports; establishments of physical culture and sports; relevant authorities. In fact, only the latter are subjects of state regulation of the field of sports and sports. In view of the functional criterion, the following are distinguished: the President of Ukraine, the Verkhovna Rada of Ukraine, the Cabinet of Ministers of Ukraine, the central body of executive power implementing state policy in the field of physical culture and sports.

The circle of subjects of state regulation of the sphere of physical culture and sports is narrower than the circle of subjects of regulation of the sphere. For example, the second group of entities is local government in Ukraine. The main subject of state-legal regulation of the sphere of physical culture and sports, of course, is the state, but its constitutional-legal status needs to be clarified.

The legal status of the subjects of state-legal regulation of the sphere of physical culture and sports is a complex, multidimensional and integration category of systemic character, which objectively reflects the positive and negative features of the political-legal system of the state. This is a legally-mandated position or provision of a specially authorized entity, which is expressed in the existing set of powers, duties; responsibility, reflects the regulated relationship with other participants in the public relations of the respective spheres of life.

On the basis of the study of constituent elements, as well as the results of its implementation, certain problems in this field were identified, directions and ways of improvement of such status, corresponding normative legal bases and practice of implementation were outlined.

Keywords: physical culture, sport, sport relations, state, legal regulation, legislation, state authorities.

DOI: $10.33766 / 2524-0323.89 .33-44$

УДК 342.729:340.113

\author{
М. А. Самбор, \\ кандидат юридичних наук, \\ начальник сектора моніторингу \\ Прилуцького відділу поліції \\ Головного управління Національної поліції \\ в Чернігівській області \\ (м. Чернігів - м. Прилуки, Україна) \\ e-mail: NIKOLAS783@ukr.net \\ iDhttps:/ / orcid.org/ 0000-0002-0446-3892
}

\section{ОСОБЛИВОСТІ ЮРИДИЧНОЇ ТЕРМІНОЛОГІЇ У ФОРМУЛЮВАННІ ПОНЯТТЯ ПРАВА НА СВОБОДУ МИРНИХ ЗІБРАНЬ}

У статті досліджуються особливості використання юридичної термінології, покликаної формулювати в змісті нормативно-правових актів національного законодавства України поняття права на свободу мирних зібрань. Аналіз національного законодавства України дозволив зробити висновок про те, що для позначення права на свободу мирних зібрань законодавець використовує різні конструкції, а саме «право на свободу мирних

(C) Самбор М. А., 2020 